\title{
A JURISDIÇÃO DOS CAPITÃES EM MINAS GERAIS, NO INÍCIO DO SÉCULO XIX - O PAPEL DE JANUÁRIO GARCIA LEAL, O “SETE ORELHAS"
}

\author{
CAPITAINS' JURISDICTION IN THE STATE OF MINAS GERAIS IN THE BEGINNING OF $19^{\text {TH }}$ \\ CENTURY - THE ROLE OF JANUÁRIO GARCIA LEAL, THE "SETE ORELHAS"
}

Acacio Vaz de Lima Filho*

\begin{abstract}
Resumo:
Neste artigo, que reproduz uma palestra por nós dada para Oficiais da Força Pública do Estado de São Paulo, abordamos o fenômeno da "Jurisdição dos Capitães", presente em Minas Gerais nas três primeiras décadas do século XIX. O surgimento da jurisdição atípica dos Capitães das Companhias de Ordenanças é inseparável da omissão do Estado português da época, com o corolário da displicência das autoridades constituídas. Buscamos demonstrar que na atual sociedade brasileira, em que o crime organizado se transformou em um poder paralelo, um "Estado dentro do Estado", os "justiceiros" constituem, de certa forma, uma repetição, pior, da "Jurisdição dos Capitães."

Palavras-chave: Capitania de Minas Gerais. Decadência da mineração. Omissão do Estado português. Jurisdição paralela. A ausência de atividade das autoridades constituídas. Apoio da população aos justiceiros. Prisão decretada pelo Príncipe Regente. Inutilidade da medida.
\end{abstract}

\begin{abstract}
:
This paper, which summarizes my lecture to the officers of the State of São Paulo Police, presents the phenomenon of "Jurisdiction of the Captains" in the State of Minas Gerais in the first three decades of the 19th century. The emergence of an atypical jurisdiction of the Captains of the Ordinances Company is inseparable of the omission of the Portuguese State at that time, based on the corollary of the negligence of authorities. The current Brazilian society, in which organized crime has become a parallel power, a "state within a state", the "justiceiros" have been, in a way, a bad repetition of the "Captains' Jurisdiction."

Keywords: Province of Minas Gerais. Mining decay. Failure by the Portuguese State. Parallel jurisdiction. The lack of activity of the constituted authorities. Popular support to "justiceiros". Arrest by the Prince Regent. Useless measures.
\end{abstract}

"Não cora o livro de ombrear c'o sabre, nem cora o sabre de chamá-lo irmão" (Castro Alves)

\footnotetext{
Advogado e historiador. Doutor em Direito pela Faculdade de Direito da Universidade de São Paulo. Palestra, convertida em artigo, que foi realizada na Corporação Brigadeiro Rafael Tobias de Aguiar da Força Pública do Estado de São Paulo.
} 
Introdução

Desejo de plano, ante tão seleto auditório, agradecer a oportunidade - que me é muito cara - de me dirigir à Oficialidade da gloriosa corporação do Brigadeiro Rafael Tobias de Aguiar. Sou, modéstia à parte, um velho amigo da Força Pública do Estado de São Paulo, e como paulista, advogado militante e cidadão, tenho muito orgulho dela. Vários dos meus parentes integraram as fileiras da milícia de Tobias. Entre eles, meu tio paterno, o Tenente Coronel Sinésio Netto de Lima, e o meu primo, Coronel Milton Cabral de Vasconcellos. E, como aluno do Curso de Cavalaria do Centro de Preparação dos Oficiais da Reserva de São Paulo, CPOR/SP, fiz uso do "stand" de tiro da Academia do Barro Branco, e lá participei dos ousados "exteriores" comandados por meu instrutor, o então Capitão Abraão João Farah. Acampei no Barro Branco, onde participei de patrulhas noturnas. Assim, o meu vínculo com este ambiente é antigo, sólido e estreito. A ele se aplica a definição de "amizade" formulada pelo grande Aristóteles: - Ela é a dedicação contínua e desinteressada de uma pessoa a outra.

Ao ser recebido em um ambiente militar, em um meio de estudo nitidamente castrense, lembro que a oposição entre o "Civil” e o "Militar", habilmente explorada há muito tempo pela propaganda do internacionalismo comunista, não tem qualquer razão de ser, quer do ponto de vista ontológico, quer do lógico, quer do histórico. Em Roma, o "Civis", vale dizer, o "Cidadão" era ao mesmo tempo o soldado. De resto, uma das traduções da palavra "Civis, is" dada pelo ilustre latinista Francisco Torrinha, é a de "soldado romano". ${ }^{1}$ E nas diversas "Poleis" da velha Hélade, também existe esta equivalência entre o "Cidadão" e o "Soldado.” Ensina Gustave Glotz que nas reformas do legislador Sólon, que constituíram o embrião da chamada "Democracia Ateniense", os "Polites" das quatro classes censitárias prestavam o serviço militar, de acordo com o seu censo. ${ }^{2}$

Sequer na Grécia ou em Roma jamais houve um antagonismo entre o "Civil" e o "Militar", segue-se que esta pretensa incompatibilidade é de todo estranha à Cultura do Ocidente. O "Ocidente", no dizer feliz do grande e saudoso Professor Miguel Reale, é uma síntese do "Logos" da Filosofia Grega, da "Voluntas" do Direito Romano" e da "Caritas" do Cristianismo. ${ }^{3}$ Ainda de acordo com o ensinamento de Miguel Reale, o gênio grego, voltado para o uso especulativo da razão, para o saber pelo saber, teve na Filosofia a sua maior criação. O Povo romano, prático, realista, vocacionado para as realizações concretas, criou o Direito. ${ }^{4}$ E o contributo do Cristianismo para o Ocidente foi

Vide TORRINHA, Francisco. Dicionário Latino-Português. 3. ed. Porto: Edições Marânus, 1945. p. 151.

2 Vide GLOTZ, Gustave. A Cidade Grega. 2. ed. Tradução de Henrique de Araujo Mesquita e Roberto Cortes de Lacerda. Rio de Janeiro: Editora Bertrand Brasil S.A., 1988. p. 101 e 102.

3 Citamos de memória.

4 Vide REALE, Miguel. Horizontes do direito e da história. 2. ed. rev. e auml. São Paulo: Saraiva, 1977. p. 55. 
a "Caritas"; vale dizer, a "Caridade", um conceito estranho à mundividência dos helenos e dos romanos.

Este "Ocidente", repito e enfatizo, repele qualquer antagonismo ou incompatibilidade entre o "Civil" e o "Militar"; porquanto, o pleno exercício da "Cidadania", na Grécia e em Roma, pressupunha a prestação do serviço militar, encarada como uma honra. Não olvidemos - e já o registramos em trabalho anterior - que se tratava de uma "Cidadania Ativa", calcada na "Isonomia", vista como o privilégio de obediência às mesmas leis. ${ }^{5} \mathrm{~A}$ tal ponto era importante este privilégio de obediência às leis, que, segundo registra a História, nas Termópilas, local de sacrifício de Leônidas e os seus "Trezentos", os lacedemônios construíram um monumento, no qual gravaram os versos do poeta Simônides: - "Caminhante, vai a Esparta dizer que aqui morremos para cumprir as suas leis." 6

Ao abordar este assunto, da complementaridade existente entre o "Civil" e o "Militar", me vêm à memória as palavras do General Plínio Pitaluga, meu saudoso comandante na Quarta Divisão de Cavalaria, ao se dirigir aos Oficiais e Praças da minha unidade, o inolvidável $17^{\circ}$ Regimento de Cavalaria, com quartel em Amambai, Mato Grosso, no já longínquo ano de 1972: - Senhores, nós todos nascemos civis, saímos da vida civil, e um dia voltamos à vida civil!" Estas palavras do antigo Comandante do "Esquadrão Tenente Amaro" dizem tudo. Não há a necessidade de acrescentar coisa alguma à matéria.

Quero registrar a minha gratidão por aqui estar. E evocar uma figura ímpar que muito honrou esta corporação, e que, na vida civil, foi um notável professor da Universidade Presbiteriana Mackenzie, onde leciono. Refiro-me ao saudoso Coronel Nelson Freire Terra. Oficial dotado de inteligência brilhante, de uma impecável formação militar e policial, e de uma sólida cultura humanística, foi ele um dos homens mais ilustres de uma geração que foi, ela própria, ilustre. A presença do Coronel Terra na Faculdade de Direito da Universidade Presbiteriana Mackenzie, não foi e nem será esquecida por seus colegas e por seus antigos alunos. E ela me autoriza a dizer: - Senhores, eu não estou vindo à Força Pública; eu estou voltando à Força Pública!...

Insisto nesta denominação, antiga, profundamente paulista, e que tem por ela a tradição muito mais que secular. De acordo com a Filosofia Aristotélico-Tomista, "Os nomes derivam das coisas", frase que em Latim - a língua da Ciência do Direito assim fica enunciada: - "Nomina sunt consequentia rerum." Nesta ordem de ideias, os nomes traduzem, revelam, a essência das coisas. E "essência”, na impecável definição de Goffredo da Silva Telles Junior, é aquilo pelo que uma coisa é o que é, e pelo que se

Vide LIMA FILHO, Acacio Vaz de. Liberdade antiga e liberdade moderna, no pensamento de Miguel Reale. Revista Brasileira de Filosofia, São Paulo, v. 55, n. 222, abr./jun. 2006.

6 Citamos de memória. 
distingue das demais coisas. ${ }^{7}$ Ora, o nome "Força Pública" é revelador da essência desta gloriosa corporação. Já os romanos distinguiam entre a força bruta e a força a serviço do Direito. A primeira era a "Vis Cruenta", e a segunda, a "Vis Compulsiva". E a essência desta impertérrita milícia sempre foi o uso da força em prol da Ordem Jurídica e da defesa da segurança dos cidadãos. "Força Pública", portanto!... aquela mesma dos combates feros de Itararé, da rígida tradição militar da "Missão Francesa", e das "Escoltas de Captura" que, nas primeiras décadas do século passado, livraram o sertão do Estado de São Paulo das tropelias dos facínoras como o famigerado Diogo da Rocha Figueira, o "Dioguinho."

1. Breves noções etimológicas: - as palavras "jurisdição" e "capitães"

A palavra portuguesa "Jurisdição" deriva da palavra latina "Jurisdictio, onis", um vocábulo imparissilábico da terceira declinação, do gênero feminino. De acordo com F.R. dos Santos Saraiva, entre outros significados, o vocábulo latino tem os seguintes: - "Acção de administrar justiça, judicatura", "direito de administrar justiça”, "jurisdicção", "sede de justiça", "alçada" e "tribunal." "Jurisdictio", ainda segundo Saraiva, resulta de "Jus" e de "Dictio." "Jus, juris", palavra também da terceira declinação, do gênero neutro, tem - entre outros - os significados de "direito", "equidade" e "justiça."10 "Dictio, onis", por seu turno, é também uma palavra da terceira declinação latina, imparissilábica e do gênero feminino. Em meio a outros significados, possui os de "acção de dizer", "parecer expresso", "dicção" e "expressão."11 "Dictio, onis", por sua vez - ainda de acordo com o clássico Dicionário Saraiva - se relaciona com "dicere", que é o infinito do verbo transitivo da terceira conjugação "Dico", cujos tempos primitivos são "Dico, is, ixi, ctum, cere", que tem para o vernáculo as seguintes traduções: - "dizer", "exprimir", "recitar" e "fallar em publico."12

As sumárias noções etimológicas que abordamos, permitem-nos dizer que a "Jurisdictio", ou em língua vulgar, a "Jurisdição", é a dicção do Direito. Mas esta noção não é suficiente ao nosso propósito. Temos que aprofundá-la, adentrando o campo da Ciência do Direito - chamada pelos romanos, como bem lembra Miguel Reale, de "Jurisprudentia", vale dizer, a "prudência do Direito"13 - e, mais especificamente, o campo do Direito Processual, que se encarrega da definição de "Jurisdição" à luz da Dogmática Jurídica.

Citamos de memória.

Vide SARAIVA, F. R. dos Santos. Dicionário Latino-Português. Belo Horizonte/Rio de Janeiro: Livraria Garnier, 2006. p. 648.

9 Id. Ibid.

$10 \quad$ Id,. Ibid., p. 649.

11 Vide Id. Ibid., p. 371.

12 Id. Ibid., p. 370.

13 Vide REALE, Miguel. Lições preliminares de direito. 27. ed. ajustada ao novo Código Civil, 4. tir. São Paulo: Editora Saraiva, 2004. p. 62. 
De acordo com o eminente e saudoso Professor José Frederico Marques, aliás, um dos integrantes do núcleo inicial da famosa "Escola de Processo de São Paulo", a Jurisdição é a função que o Estado desenvolve no processo, para aplicar a lei e fazer justiça. Aduz o ilustre filho de Batatais que a Jurisdição pode ser definida como “a aplicação do direito objetivo em relação a uma pretensão." 14

A menção ao "Estado" não deixa margem a qualquer dúvida, no sentido de ser, a Jurisdição, uma função pública, e, de resto, uma função da Soberania, que nós entendemos, na esteira do nosso querido mestre José Carlos de Ataliba Nogueira, como sendo "O poder incontrastável de querer coercitivamente e de fixar as competências."15 Da nossa parte pensamos que a moderna noção de "Soberania" deita raízes na vetusta noção de "Imperium” do Direito Público Romano. E este já foi por nós definido como "um poder soberano, originário e unitário."16

Sobre a Jurisdição, escreveu João Mendes de Almeida Junior, um dos maiores juristas da História do Brasil, estas palavras memoráveis:

- A JURISDIÇÃO, função de declarar o direito aplicável aos fatos, é a causa final específica da atividade do Poder Judiciário (*). Assim como é função própria e exclusiva do Poder Legislativo a de fazer leis (jus dare, como diziam os romanos), - a do Poder Executivo executar as leis (jus executare), - é função própria e exclusiva do Poder Judiciário dizer a lei existente aplicável a um fato ocorrente nas relações entre indivíduos (jus dicere). ${ }^{17}$

A referência ao insigne jurista patrício me traz à lembrança o seu ilustre sobrinho, Professor Joaquim Canuto Mendes de Almeida, de quem fui aluno no Largo de São Francisco, na Cadeira de Direito Processual Penal, nos idos de 1973. Ao citar o famoso jurista, o Professor Canuto, com uma solenidade cômica, dizia: - "Senhores, João Mendes de Almeida Junior, lá em casa Tio Janjão, escreveu que... etc.” O fato é que não se pode negar até hoje, às lições de João Mendes Junior, uma impressionante atualidade. Completa ele o que dissera sobre a Jurisdição escrevendo, "verbis":

São elementos constitutivos da "Jurisdição" o conhecimento do caso e o julgamento, ou como diziam os Romanos, notio et judicium. Notio compreende a atribuição de ordenar as diligências necessárias para a determinação do ponto litigioso e

14 Vide MARQUES, José Frederico. Instituições de direito processual civil. Rio de Janeiro: Forense, 1958. v. 1, p. 11-12.

15 Citamos de memória.

16 Vide LIMA FILHO, Acacio Vaz de. O poder na antigüidade: aspectos históricos e jurídicos. São Paulo: Ícone Editora, 1999. p. 233.

17 Vide ALMEIDA JUNIOR, João Mendes de. Direito judiciário brasileiro. 5. ed. Rio de Janeiro/São Paulo: Livraria Freitas Bastos S.A., 1960. p. 40. (Maiúsculas e itálico no original). 
prova do fato e circunstâncias; judicium consiste na decisão de causa, proferindo o juiz a sentença declarando o direito aplicável, ou impondo uma pena legal. ${ }^{18}$

O filólogo e o cultor do Direito têm que caminhar juntos. Não é demasia lembrar aqui, na esteira do latinista português Francisco Torrinha, que "notio, onis", um substantivo do gênero feminino da terceira declinação, imparissílabo, apresenta inclusive - os seguintes significados: - "Acção de conhecer", "conhecimento", "noção", "idéia", "conhecimento duma causa" e "exame judicial". ${ }^{19}$ Não deixa de ser expressivo que, quando pedimos a alguém que nos dê uma "noção" de determinado assunto, a rigor estamos a pedir que nos seja dado o "conhecimento" daquele assunto!... o que aqui importa é que, como é básico em Direito Processual, o Juiz decide após "regular conhecimento", isto é, após formar a sua convicção sobre o assunto a ser decidido. Com a sua convicção formada, o Juiz profere a sua "Sentença." A etimologia do vocábulo "Juiz" é altamente expressiva; Miguel Reale chama a atenção para a "correlação esclarecedora" existente entre as palavras "Juízo" e "Juiz". ${ }^{20}$ E significativa também, aduzimos, é a etimologia da palavra portuguesa "Sentença", uma vez que, na "Sentença", o Juiz de Direito revela, manifesta, o que "sente" a propósito da causa.

Passemos, agora, à palavra “Capitão", que na nomenclatura das nossas classes armadas, designa um determinado círculo da Oficialidade, ubicado entre o "Círculo dos Oficiais Subalternos", e o "Círculo dos Oficiais Superiores.” Minhas memórias castrenses apontam para o fato de que ao Capitão incumbe, na Arma de Cavalaria, o comando de esquadrão, sendo que lhe cabe, na Arma de Infantaria, o comando de companhia. É ademais corrente a expressão "Capitão de Indústria", para designar o homem que, no setor industrial, exerce determinado comando, possuindo de conseguinte um certo grau de liderança no ramo.

No Latim - e o Português é um dos idiomas "neolatinos" ou "novilatinos" - a palavra se relaciona intimamente com o vocábulo "Caput, capitis", um substantivo neutro da terceira declinação, imparissílabo, que, de acordo com o conspícuo latinista Nicolau Firmino, tem os significados de "cabeça", "ponta", "cabo", "fim", "indivíduo", "vida", "chefe", "capítulo", "parágrafo", "resumo" e "sumário". ${ }^{21}$ Como é evidente, de todos esses significados, aos nossos fins interessam fundamentalmente os de "cabeça" e "chefe." Nesta ordem de ideias, não é ocioso lembrar que "cabecilha" é um dos sinônimos da palavra

18 Vide ALMEIDA JUNIOR, João Mendes de. Direito judiciário brasileiro. 5. ed. Rio de Janeiro/São Paulo: Livraria Freitas Bastos S.A., 1960. p. 40-41. (Maiúsculas e itálico no original).

19 Vide TORRINHA, Francisco. Dicionário Latino-Português. 3. ed. Porto: Edições Marânus, 1945. p. 560.

20 Vide REALE, Miguel. Lições preliminares de direito. 27. ed. ajustada ao novo Código Civil, 4. tir. São Paulo: Editora Saraiva, 2004. p. 84-85.

${ }^{21}$ Vide FIRMINO, Nicolau. Dicionário Latino-Português. 2. ed. rev. e ampl. São Paulo: Edições Melhoramentos, s/d. p. 78. 
"chefe"... de acordo com o mesmo latinista, "Capito, onis", um outro substantivo da terceira declinação, do gênero neutro e, evidentemente, imparissilábico, tem os significados de "cabeçudo", "que tem cabeça grande". ${ }^{22}$ Já o famoso "Dicionário Saraiva", além de registrar o significado de "o que tem cabeça grande" dá a palavra como nome de homem. ${ }^{23}$ Nesta ordem de ideias lembramos, com apoio em Vincenzo Arangio-Ruiz, que na época do Imperador Augusto viveu, em Roma, um jurista insigne, chamado C. Ateio Capitão. ${ }^{24}$

Antônio Geraldo da Cunha, em seu "Dicionário Etimológico", sob o verbete em epígrafe ensina que a palavra deriva do Baixo Latim "Capitanus", sendo que, no século XIV, era admitida a grafia "Capitam", ficando o plural "Capitãaes." A palavra portuguesa, de acordo com a mesma fonte, é do gênero masculino, significando "chefe", "comandante" e "cabeça". Existe o verbo "Capitanear", remontando ao século XVI, e bem assim o substantivo feminino "Capitania", este com os significados de "comando" e “chefia”. Estes significados existem em vernáculo desde o século XV. Por derradeiro, há o vocábulo "Capitânia”, um adjetivo sobre o qual escreve o autor: - "diz-se de, ou embarcação em que se acha o comandante (capitão) de uma força naval". ${ }^{25}$ Lembramos que a palavra "Capitania" muito importa à História do Brasil, em função do sistema das "Capitanias Hereditárias", aqui implantado por El-Rei de Portugal no século XVI, e cujo resgate histórico foi magnificamente feito pelo ilustre historiador e geógrafo patrício, Professor José Baptista de Carvalho, em sua notável obra "A Verdadeira História Das Capitanias Hereditárias". ${ }^{26}$ Demonstra com efeito o Professor José Baptista de Carvalho, que, contrariamente à vulgata propalada por certa historiografia ideologicamente tendenciosa, as Capitanias Hereditárias atingiram plenamente, no Brasil, o "desideratum" para o qual foram criadas, qual seja: - a ocupação dos novos territórios. Registra José Baptista de Carvalho a respeito, "verbis": - "As Capitanias Hereditárias cumpriram seu papel histórico ocupando um território até então inaproveitado e à disposição da cobiça internacional, que o descobrimento da América despertou". ${ }^{27} \mathrm{E}$ mais adiante registra o ilustre historiador:

- Em conclusão, pode-se afirmar que, apesar do seu fraco desenvolvimento econômico no início, as capitanias hereditárias desempenharam importante papel estratégico

\footnotetext{
22 Vide FIRMINO, Nicolau. Dicionário Latino-Português. 2. ed. rev. e ampl. São Paulo: Edições Melhoramentos, s/d. p. 77.

23 Vide Id. Ibid., p. 180.

24 Vide ARANGIO-RUIZ, Vincenzo. Storia del diritto romano. 6. ed. Napoli: Casa Editrice Dott. Eugenio Jovene, 1950. p. 278-279.

25 Vide CUNHA, Antônio Geraldo da. Dicionário etimológico nova fronteira da língua portuguesa. 1. ed., 2. reimp. Rio de Janeiro: Nova Fronteira, 1982. p. 151.

26 CARVALHO, José Baptista de. A verdadeira história das capitanias hereditárias. São Paulo: edição do autor, 2008.

$27 \quad$ Vide Id. Ibid., p. 18.
} 
realizando o povoamento do litoral, e posteriormente o desbravamento e ocupação do sertão. A implantação e desenvolvimento da atividade econômica exportadora $e$ a descoberta de ouro e pedras preciosas no final do século $X V I I$, foi conseqüência dessa expansão. ${ }^{28}$

A nossa temática se imbrica com a exploração do ouro nas Minas Gerais. Destarte, é oportuna a última remissão à mencionada obra sobre as Capitanias Hereditárias. A palavra "Capitão" é utilizada na epopeia maior do idioma. Com efeito, Camões, no Canto Quinto dos "Lusíadas” escreve, na estrofe 19:

Em fim não houve forte capitão,

Que não fosse também douto e sciente,

Da Lacia, Grega, ou barbara nação,

Se não da Portugueza tão sómente. ${ }^{29}$

Feitas essas considerações etimológicas, podemos concluir que pela expressão "Jurisdição dos Capitães", deve ser entendido o exercício de "dizer o Direito", por parte de Capitães. Quando, onde e como isto se deu, é o que veremos no desenvolvimento desta palestra.

2. As condições em que se encontrava a capitania das Minas Gerais, no dealbar do século XIX

Como nos foi dado verificar da lição do Professor José Baptista de Carvalho, há pouco examinada, a descoberta do ouro no Brasil no final do século XVII foi uma consequência da oportuna implantação pelos portugueses, em terras do Novo Mundo, do sistema das Capitanias Hereditárias, experimentado com êxito, ao longo da gesta da talassocracia, na colonização dos Açores, da Madeira e de Cabo Verde. Seja dito aliás, que o gênio colonizador do Povo português não foi jamais igualado por nenhum outro povo, ao longo da História, com a possível exceção do Povo Romano.

A propósito da matéria ora enfocada, dizia o Professor Antonio de Oliveira Salazar que os portugueses, que provinham de uma intensa mistura de povos e de etnias - romanos, gregos, cartagineses, germanos, árabes, mouros e judeus - tinham a ímpar capacidade de, a um tempo, assimilar outros povos, e ser por eles assimilados ${ }^{30}$ Os frutos da colonização lusíada atestam o acerto destas palavras: - Não conhecemos, com a graça

\footnotetext{
28 Vide CARVALHO, José Baptista de. A verdadeira história das capitanias hereditárias. São Paulo: edição do autor, 2008. p. 19. (Os grifos em itálico são nossos).

29 Vide CAMÕES, Luiz Vaz de. Os Lusíadas. 5. ed. edição escolar comentada pelo Professor Otoniel Mota. São Paulo: Edições Melhoramentos, s/d. p. 193.

30 Citamos de memória.
} 
de Deus, a miséria moral do racismo e da segregação, marco das colonizações inglesa e holandesa!... e este dado deve servir de resposta, cabal, aos desinformados que, inda hoje, lamentam a expulsão dos holandeses de Pernambuco!

Detentor de um exíguo potencial demográfico, Portugal logrou colonizar o Brasil, um país de dimensões continentais. E a exploração do ouro a partir do final do século XVII, foi um dos corolários do profundo senso de Geopolítica daquele país a quem a Providência havia reservado o lugar de "proa da Europa"...

Sobre o ouro das Minas Gerais, damos a palavra a Pedro Taques de Almeida

Paes Leme:

De São Paulo mandou o Capitão General para as Minas ao Paulista Manoel Lopes de Medeiros para nelas repartir as datas pela Portaria do teor seguinte: 'Por algumas noticias, que me têm chegado do Sertão de que nas Minas tem havido algumas desordens todas prejudiciais ao serviço de Sua Majestade, que Deus guarde e ao bem comum dos que habitam àquele lugar; por ser mui conveniente atalhar semelhantes perturbações, e juntamente dar forma à repartição dos Ribeiros, porque da confusão de não haver forma neste negócio nascem as desordens que até aquí se tem experimentado do que resultam mortes e pendências com bando de parte à parte; e como este particular é de tanta ponderação, aliás consideração, me obriga buscar-lhe o remédio pronto e para este ser eficaz, carece de pessoa de atividade e respeito o que tudo concorre na pessoa do Sargento Mor Manoel Lopes de Medeiros ao qual ordeno vá às Minas dos Cataguazes e seu distrito, a repartir as datas dos Ribeiros descobertos e que se descobrirem, conformandose com o Regimento que lhe mandei passar em quatro de Fevereiro presente dando-o à execução inviolavelmente examinará em companhia do Capitão João Carvalho as Minas que se suspeitam ser de Prata, ou de outros quaisquer metais de que tiver notícia, e de tudo me dará conta para eu dar a Sua Majestade, que Deus guarde, esta minha ordem se registrará nos livros de seu assento para que a todo o tempo conste a diligência a que o mando. São Paulo dez de Fevereiro de mil setecentos anos --- Artur de Sá e Menezes.' (Cart. da Provedoria da Fazenda liv. de Reg. capa de Olandilha n. 5, $\mathrm{tt}^{\mathrm{o}}$ 1693 até 710 , p. 96). ${ }^{31}$

31 Vide LEME, Pedro Taques de Almeida Paes. Notícias das minas de São Paulo e dos sertões da mesma capitania. Segunda tiragem da edição comemorativa do IV Centenário da Fundação de São Paulo, introdução e notas de Afonso de E. Taunay. São Paulo: Livraria Martins Editora S.A., p. 85 e 86. 
Verificamos, da citação de Pedro Taques, que o Estado português, diante da ocorrência da descoberta do "ouro das Gerais", tomou providências, enérgicas e eficazes, para proporcionar segurança e ordem à população da região aurífera.

Ainda no início do século XVIII, El-Rei de Portugal, levando em conta estarem as minas de Sabará e de Cataguazes "ainda no estado de Arraiais", e com uma população integrada por paulistas, por brasileiros de outras regiões, e por pessoas vindas da Europa, existindo muitos escravos e "sem figura alguma de juízo para administração da Justiça no civil e Crime", resolveu criar um "Ministro de Letras" com amplíssima jurisdição "em todas as matérias de minerar e do Civel e Crime e de sua Real Fazenda e quintos dela e da fazenda dos defuntos e ausentes", tendo recaído a escolha na pessoa do Doutor José Vaz Pinto, nomeado Superintendente Geral das Minas, isto no ano de 1702. Insisto no pormenor, revelador de que, no início do ciclo da mineração, e até o apogeu de tal ciclo, o Estado Português não estava ausente.

Aqui não nos ocuparemos de toda a história do famoso "ouro das Gerais", o que nos desviaria sobremodo do leito principal da nossa exposição. Baste-nos dizer que um dia a mineração do ouro nas Minas Gerais entrou em decadência, o que gerou consequências nefastas para toda a região aurífera. A esta decadência da atividade mineradora, está ligada a "Jurisdição dos Capitães", tema da nossa palestra.

Um grande, notável estudioso do tema "Jurisdição dos Capitães", é o Dr. Marcos Paulo de Souza Miranda, integrante do Ministério Público do Estado de Minas Gerais, Sócio do Colégio Brasileiro de Genealogia, Sócio da Associação Brasileira dos Pesquisadores de História e Genealogia, e Conselheiro Administrativo do Núcleo de Pesquisas Arqueológicas do Alto Rio Grande. Sua obra "Jurisdição dos Capitães", que tem o subtítulo "A história de Januário Garcia Leal, o Sete Orelhas, e seu bando", ${ }^{32}$ teve o condão de despertar o nosso interesse pelo assunto. Lido o livro do jovem Promotor de Justiça, não hesitamos em incluir no programa da disciplina "História do Direito e das Instituições Jurídicas", que temos a honra de lecionar na Faculdade de Direito da Universidade Presbiteriana Mackenzie, o ponto intitulado "A Jurisdição dos Capitães. Januário Garcia Leal." Manda a verdade consignar que o alto grau de interesse dos senhores alunos, justificou "in totum" a referida inclusão.

Vamos dar a palavra ao Dr. Marcos Paulo de Souza Miranda, a propósito das condições em que se achava a Capitania das Minas Gerais no início do século XIX. Escreve o autor, "verbis":

O cenário mineiro no início do século XIX era deprimente. As três primeiras décadas daquela centúria foram de

32 MIRANDA, Marcos Paulo de Souza. Jurisdição dos capitães: a história de Januário Garcia Leal, o Sete Orelhas e seu bando. Belo Horizonte: Del Rey, 2003. 
transformações radicais para Minas Gerais, que com o declínio da atividade mineradora experimentou uma onda de ruralização da sociedade, com reflexos imediatos na economia e na política. Exemplo contundente da decrepitude econômica da Capitania é o fato de que entre 1801 e 1830 só foram criados dois municípios em Minas (Baependi e Jacuí). Os viajantes estrangeiros que visitaram Minas naquela época não deixaram de registrar tais fatos. O francês Sait-Hilaire disse que era fácil encontrar pessoas maltrapilhas e esfarrapadas nas vazias cidades esvaziadas do ouro. Spix e Martius, passando pela Comarca do Rio das Mortes (onde ocorreram os fatos a seguir narrados), observavam que por lá reinavam a ruína e a selvageria e que até as estradas morriam abandonadas. O comerciante inglês John Mawe também faz uma descrição sombria sobre Serro, Conceição do Mato Dentro e Itambé. ${ }^{33}$

Aduz o Autor que o Estado português "nada fazia para minimizar a caótica situação vivida pelos mineiros". ${ }^{34}$ Como veremos no decorrer da exposição, a inércia, melhor ainda, a verdadeira ausência do Estado português na região, em grande medida explica e mesmo justifica - a existência do fenômeno denominado "Jurisdição dos Capitães." E isto porquanto a ineficiência e a omissão das autoridades constituídas da Colônia, eram um convite à realização da justiça pelas próprias mãos. Marcos Paulo de Souza Miranda traz, em abono do que diz, as seguintes palavras do célebre cientista francês Auguste de SaintHilaire, que passou por Minas Gerais, em demanda das nascentes do Rio São Francisco:

Os homens mais tranqüilos e mais felizes que há no Brasil são os homens que vivem em lugares distantes do fórum. Quando surge alguma disputa entre eles a questão é resolvida amigavelmente, ou então faz-se justiça pelas próprias mãos... matando-se o desafeto. É a barbárie, não há dúvida, mas não é muito pior, certamente, do que a maneira pela qual a justiça é feita, pois a parcialidade inerente aos juízes traz quase sempre como resultado que nunca seja o mais fraco e o pobre que esteja com a razão. Os processos arruínam as famílias, e uma vez formado um projeto de vingança não há de ser o temor da justiça que irá impedir a sua execução... um velho de oitenta anos, que amava a Deus e seus semelhantes, contou-me que tinha mudado de domicílio várias vezes, escolhendo sempre lugares onde não havia chegado ainda nenhuma autoridade judiciária, civil ou

\footnotetext{
33 Vide MIRANDA, Marcos Paulo de Souza. Jurisdição dos capitães: a história de Januário Garcia Leal, o Sete Orelhas e seu bando. Belo Horizonte: Del Rey, 2003. p. 63. (Os grifos em itálico são nossos).

34 Id. Ibid.
} 
eclesiástica, não que tivesse cometido qualquer crime, mas porque temia que lhe imputasse algum. ${ }^{35}$

Em função do quadro aqui bosquejado, escreve Marcos Paulo de Souza Miranda, em muitas regiões da Capitania de Minas Gerais, e em especial, naquelas partes mais retiradas da Capitania, a pessoa que dominava o exercício precário da Justiça era o Capitão Mor de Ordenanças, escolhido entre os indivíduos mais ricos, um genuíno Delegado de Polícia que - a seu modo - punia os criminosos e prevenia as infrações. Exercia em tais casos, "uma autoridade plenária e absoluta, resumindo em suas mãos todo o poder de julgar e punir discricionariamente."36

\section{O que eram as "companhias de ordenanças"}

Marcos Paulo de Souza Miranda conceitua as "Companhias de Ordenanças” como uma organização da população civil, de caráter militar, para a defesa local em caso de ataque inimigo. ${ }^{37} \mathrm{E}$, da nossa parte, aduzimos que as mencionadas "Companhias de Ordenanças" tiveram um papel importante na vida do Brasil Colônia.

Podemos dizer, com alguma segurança, que se tratava de uma milícia, cujos postos eram preenchidos por iniciativa das Câmaras Municipais, que enviavam listas tríplices ao Governador da Capitania. Este passava as Cartas Patentes, sujeitas a ratificação por El-Rei. Aqui é preciso que rememoremos o dado de que muito importante foi o papel das Câmaras Municipais no Brasil Colônia: - Tal papel está em consonância com a realidade social e econômica do Brasil à época, escrevendo Claudio De Cicco, com a sua habitual clarividência:

Se bem que haja uma correlação entre o ambiente rural e o patriarcalismo, não se pode esquecer que as vilas e cidades vieram como prolongamento das casasgrandes. Ataliba Nogueira analisou a formação do município no Brasil e mostrou que, apesar de conservar o nome romano, teve origem diversa: nasceu não como prolongamento do Estado, como na Europa, mas como ponto de encontro dos senhores das fazendas e engenhos, geralmente por ocasião de festividades religiosas, ao redor das capelas, quando então se combinavam casamentos, se fechavam negócios, aproveitando-se o registro paroquial como assentamento, na falta de um registro civil, do Estado. Não foi por simples coincidência que, no desenvolvimento da vida municipal, foram vereadores das Câmaras

\footnotetext{
35 "Viagem às nascentes do rio São Francisco", p. 37, apud MIRANDA, Marcos Paulo de Souza. Jurisdição dos capitães: a história de Januário Garcia Leal, o Sete Orelhas e seu bando. Belo Horizonte: Del Rey, 2003. p. 64-65.

36 Vide MIRANDA, Marcos Paulo de Souza. Jurisdição dos capitães: a história de Januário Garcia Leal, o Sete Orelhas e seu bando. Belo Horizonte: Del Rey, 2003. p. 65.

$37 \quad$ Vide Id. Ibid., p. 58.
} 
sempre os 'homens bons da terra', vale dizer, os patriarcas, que pelo seu poder econômico e prestígio político se impunham na região. ${ }^{38}$

Enfatiza Marcos Paulo de Souza Miranda que, no Brasil Colonial, a ocupação de postos milicianos era um fator socialmente importante, e que significava prestígio para aquele que ocupasse um posto. ${ }^{39}$ Como é evidente, a condição de "homem bom" era um requisito indispensável para ocupar os postos das Companhias de Ordenanças, como era indispensável para exercer a Vereança.

Em benefício da clareza, convém que elucidemos, a esta altura, o que era ser um "homem bom", na sociedade colonial. De acordo com Ronaldo Vainfas, citado por Marcos Paulo de Souza Miranda, a expressão "Homem bom”, na América portuguesa, designava os indivíduos bem-aceitos pela sociedade e pelo governo. E nesta aceitação, mais do que os predicados de caráter, eram levados em conta os seguintes fatores: - Cor, ascendência, estado civil, ocupação, o exercício de postos na milícia e a fortuna pessoal. Ainda de acordo com Ronaldo Vainfas, tratava-se de uma atitude mental típica do Antigo Regime, que não considerava os indivíduos como nascidos iguais, e dotados dos mesmos direitos. ${ }^{40}$

Januário Garcia Leal, que centraliza com a sua personalidade o estudo monográfico de Marcos Paulo de Souza Miranda, era um "homem bom”, na sociedade colonial da Capitania das Minas Gerais do início do século XIX. Assim, é necessário que nos debrucemos sobre as suas origens familiares, o que faremos agora.

\section{A família Garcia Leal: - suas origens e sua importância}

Ao curarmos da Família Garcia Leal, temos que remontar ao Arquipélago dos Açores, ubicado no Atlântico Norte, a uma distância de 760 milhas de Lisboa, e integrante de Portugal, porquanto a família de que nos ocupamos daí é originária. O arquipélago é composto por nove ilhas de origem vulcânica, que são as de Santa Maria, São Miguel, Terceira, Graciosa, São Jorge, Pico, Corvo, Flores e Faial. Em termos sintéticos, pode-se dizer que o Arquipélago dos Açores foi descoberto pelos navegantes portugueses no século XV. ${ }^{41}$

Antiga é a emigração açoriana para o Brasil, e lembramos a propósito que a cidade de Porto Alegre, no Rio Grande do Sul, foi fundada por casais açorianos, sendo chamada, no início, de "Porto dos Casais." Entretanto, tal emigração cresceu muito,

\footnotetext{
38 Vide DE CICCO, Claudio. Direito: tradição e modernidade. São Paulo: Ícone Editora Ltda., 1993, p. 71.

39 Vide MIRANDA, Marcos Paulo de Souza. Jurisdição dos capitães: a história de Januário Garcia Leal, o Sete Orelhas e seu bando. Belo Horizonte: Del Rey, 2003.

40 VAINFAS, Ronaldo. Dicionário do Brasil Colonial (1500 - 1808), p. 284, apud MIRANDA, Marcos Paulo de Souza. Jurisdição dos capitães... cit., p. 54.

41 Vide MIRANDA, Marcos Paulo de Souza. Jurisdição dos capitães... cit., p. 9 e 10.
} 
segundo Marcos Paulo de Souza Miranda, a partir do início do século XVIII, com a descoberta do ouro nas Minas Gerais, "para onde passaram incontáveis levas daqueles homens simples, laboriosos e honrados, que muito contribuíram para a formação da sociedade mineira." 42

Fundamental foi o papel da gente dos Açores na colonização do Brasil. E a importância intrínseca deste papel justifica que aqui registremos as palavras de Gervásio Lima, escritor açoriano de Angra do Heroísmo, transcritas por Marcos Paulo de Souza Miranda:

Não há, em todo o vastíssimo território brasileiro, povoado algum, cidade ou vila, edificação, monumento, tudo que exija trabalho, esforço, energia, que não tivesse a construí-los, a cimentá-los, braços rijos de açorianos, suor, sangue, lágrimas, ossos, cinzas dos laboriosos filhos do Arquipélago. ${ }^{43}$

É quase supérfluo acrescentar que os habitantes dos Açores são gente pugnaz, persistente e afeita à luta, tomada esta palavra em seu sentido mais amplo. E tais qualidades estavam presentes na Família Garcia Leal, oriunda do Arquipélago.

Januário Garcia Leal descendia dos Garcia da Ilha do Faial, situada na parte central do Arquipélago dos Açores. E tudo indica que a família estivesse presente na ilha, a partir de 1460. ${ }^{44}$ Ocupemo-nos agora dos Garcia no Brasil. Registra Marcos Paulo de Souza Miranda, "verbis":

A família Garcia a que nos referimos atingiu proporções gigantescas em poucas gerações no Brasil.

Enormes foram os esforços despendidos pela genealogia para se descobrir o tronco comum dos prolíferos Garcias que habitavam, sobretudo, as Capitanias de Minas Gerais e São Paulo durante a centúria setecentista. Hoje, felizmente, já se conhece a origem dessa importante estirpe, que foi uma das mais respeitadas daqueles tempos, desfrutando de grande consideração social pelos relevantes valores morais de que eram dotados seus integrantes. ${ }^{45}$

Fixemos muito bem este ponto, básico para a boa compreensão do tema que nos propusemos explorar: - A Família da qual era oriundo Januário Garcia Leal era estimada, respeitada e austera!...

Januário Garcia Leal era filho de Pedro Garcia Leal e Josefa Cordeiro Borba, recenseados em Mogi Mirim, no ano de 1767. ${ }^{46}$ Seu pai, Pedro Garcia Leal, era

\footnotetext{
42 Vide MIRANDA, Marcos Paulo de Souza. Jurisdição dos capitães: a história de Januário Garcia Leal, o Sete Orelhas e seu bando. Belo Horizonte: Del Rey, 2003. p. 11.

43 Vide Id. Ibid., p. 13.

$44 \quad$ Vide Id. Ibid., p. 17 e 18.

45 Vide Id. Ibid., p. 19. (Os grifos em itálico são nossos).

46 Vide Marcos Paulo de Souza. Jurisdição dos capitães: a história de Januário Garcia Leal, o Sete Orelhas e 
natural do Arquipélago dos Açores, tendo nascido nas ilhas por volta de 1722 . Veio ele para o Brasil, o que reforça o que temos dito sobre a intensificação da emigração açoriana no século XVIII, em conexão com a descoberta do ouro nas Minas Gerais. Contraiu matrimônio com Josefa Cordeiro Borba aos 12 de novembro de 1749, em Mogi Guaçu. Josefa Cordeiro Borba, a genitora de Januário Garcia Leal, era natural da Freguesia de Cotia, São Paulo, sendo ela própria também de origem açoriana, pelo lado paterno. E pelo lado materno, se entroncava com a família Borba Gato, o que autoriza a afirmação de que Januário Garcia Leal era um varão de inconteste cepa bandeirante. Era um homem "bem nascido", para lançarmos mão do vocabulário dos genealogistas.

Recenseados em Mogi Mirim em 1767, os pais de Januário Garcia Leal transferiram-se para a Capitania de Minas Gerais, escrevendo a respeito Marcos Paulo de Souza Miranda:

Com efeito, o casal passou a residir em Minas, onde entrou juntamente com desbravadores paulistas que exploraram a região de Jacuí, posteriormente integrada à Capitania de Minas, à procura de ouro e de escravos fugidos.

Nos primeiros assentos religiosos de Jacuí encontramos o nome de Pedro Garcia Leal contemporaneamente aos de Pedro Franco Quaresma e Bartolomeu Bueno do Prado, sendo estes dois os maiores sertanistas paulistas que demandaram aquelas plagas. ${ }^{47}$

Na citação acima, vemos a confirmação de uma antiga opinião nossa, no sentido de que, nas Minas Gerais, encontraram-se, e chegaram a conviver pacificamente, os "reinóis" (homens recentemente chegados de Portugal) e os paulistas de velha estirpe bandeirante, descobridores do ouro... e não estaria nesta providencial fusão o gérmen do fenômeno "Paulistas E Mineiros - Plantadores De Cidades", vislumbrado pelo saudoso Mario Leite?... ${ }^{48}$

A fazenda de Pedro Garcia Leal, pai de Januário, ubicada no local denominado "Talhados", ficava na margem direita do Rio Grande, lugar de passagem do antigo caminho que ligava Jacuí a São João Del Rei, no atual Município mineiro de São João Batista do Glória. De acordo com Marcos Paulo de Souza Miranda, era uma propriedade muito importante na segunda metade do século XVIII. E a prova da sua importância, é que ela aparece com destaque no mapa da Capitania de Minas Gerais feito por José Joaquim da Rocha em $1778 .^{49}$ E esta importância da propriedade, como é óbvio, milita em favor da importância da família...

seu bando. Belo Horizonte: Del Rey, 2003. p. 29.

47 Vide Id. Ibid., p. 29 e 30.

48 Citamos de memória o livro com o mesmo título, de autoria do Dr. Mario Leite.

49 Vide MIRANDA, Marcos Paulo de Souza. Jurisdição dos capitães: a história de Januário Garcia Leal, o Sete Orelhas e seu bando. Belo Horizonte: Del Rey, 2003. p. 35. 
Pedro Garcia Leal faleceu no ano de 1780 no Arraial de Jacuí, Minas Gerais. ${ }^{50}$ Dentre os seus filhos aqui nos interessam, fundamentalmente, os nomes de Januário Garcia Leal e João Garcia Leal, o primeiro, por ter protagonizado o papel de vingador e de justiceiro no exercício da "Jurisdição dos Capitães", e o segundo, pelo fato de que o seu brutal assassinato foi a causa, imediata, da atuação do seu irmão.

É básico para o desenvolvimento do nosso tema, que registremos que, oriundo de uma família ilustre e honrada, Januário Garcia Leal foi, ele próprio, fazendeiro, agricultor e pecuarista. Ao que tudo indica, dedicava-se também à exploração aurífera, sendo o dono da importante "Fazenda Ventania". ${ }^{51}$ Parece-nos importante esta origem agrária de Januário Garcia Leal. Ao escrever sobre uma época um pouco posterior, registra, com efeito, Claudio De Cicco, "verbis":

No Brasil, em 1850, o comércio e a atividade industrial ainda eram olhados com desprezo, como herança dos tempos coloniais em que as 'profissões servis' eram consideradas indignas de um homem de família de boa cepa portuguesa, de um 'filho de algo', fidalgo. ${ }^{52}$

Na reunião realizada no dia 14 de novembro de 1801, a Câmara Municipal de Campanha formulou propostas - referimo-nos às listas tríplices mencionadas "retro" para o preenchimento do posto de Capitão de uma Companhia de Ordenanças a atuar no Distrito de São José e Nossa Senhora das Dores da Freguesia de Cabo Verde. E o nome que encabeçou a lista tríplice foi o de Januário Garcia Leal. Em decorrência da indicação da Câmara Municipal de Campanha, aos 21 de janeiro de 1802, Januário recebeu a Carta Patente de Capitão, assinada pelo Governador da Capitania de Minas Gerais, Bernardo José de Lorena. ${ }^{53}$

Dois pontos têm que aqui ser destacados. Em primeiro lugar, a nomeação atesta a importância social da família e do agraciado. E, em segundo lugar, deve ser dito que a função era um "munus" público. Com efeito, os Capitães não recebiam qualquer remuneração pelo comando das Ordenanças, "mas gozavam de honras e privilégios, graças e isenções que muito valiam naqueles tempos". ${ }^{4}$

Devemos consignar que o novel Capitão de Ordenanças tomou posse das suas funções aos 13 de abril de 1802, perante o Capitão Mor, na Vila de Campanha. A

\footnotetext{
50 Vide MIRANDA, Marcos Paulo de Souza. Jurisdição dos capitães: a história de Januário Garcia Leal, o Sete Orelhas e seu bando. Belo Horizonte: Del Rey, 2003. p. 36.

51 Vide Id. Ibid., p. 55.

52 Vide DE CICCO, Cláudio. Direito: tradição e modernidade. cit., p. 84.

53 Vide MIRANDA, Marcos Paulo de Souza. op. cit., p. 58 e 59.

54 Vide Id. Ibid., p. 60.
} 
atestar a intensa catolicidade do Brasil de então, existe o dado de que, na posse, houve o termo de juramento aos Evangelhos. ${ }^{55}$

É curioso - e altamente dramático, aduzimos - que pouco depois de haver Januário Garcia Leal tomado posse do seu cargo, aos 22 de junho de 1802, a Câmara Municipal de São Bento do Tamanduá representava ao Governo português sobre "os muitos crimes praticados por Januário". ${ }^{56}$

Usamos o adjetivo "dramático", e ele é o adequado para nos referirmos à radical mudança ocorrida na vida do Capitão Januário Garcia Leal. Tal dramaticidade é muito bem captada pelo autor de "Jurisdição dos Capitães", o qual registra:

Pouco depois de ter tomado posse de seu cargo, parece ter acontecido o fato que marcou indelevelmente a vida de Januário Garcia Leal, mudando definitivamente os rumos de sua existência terrena. Como será abordado mais adiante, já em 22 de Junho de 1802, a Câmara de São Bento do Tamanduá representava ao Governo português sobre os muitos crimes praticados por Januário. Em pouco mais de dois meses, de respeitável cidadão merecedor de importante posto, passou o nosso personagem à condição de justiceiro implacável que logo teria a sua prisão decretada, ausentando-se do convívio familiar para assegurar sua liberdade debaixo de um necessário anonimato. ${ }^{57}$

Fazemos um único - e construtivo - reparo às palavras do autor. Ele se refere ao Capitão Januário Garcia Leal como sendo um "respeitável cidadão." Parece-nos que a palavra mais correta seria "súdito", e não cidadão. O Brasil era então monárquico, e monárquico permaneceria até o que chamamos de "Golpe Militar-Positivista" de 15 de novembro de $1889 .$.

A radical mudança operada na vida do Capitão Januário Garcia Leal, será abordada a seguir.

\section{O crudelíssimo assassinato de João Garcia Leal pelos filhos de Francisco Silva}

Como consignamos "retro", dos filhos de Pedro Garcia Leal nos interessam, aqui, o Capitão Januário Garcia Leal e o seu irmão João Garcia Leal. De acordo com José Teixeira de Meirelles, citado por Marcos Paulo de Souza Miranda, João Garcia Leal habitava a Fazenda Campo Formoso, situada em terras hoje pertencentes ao Município de São Bento Abade, próximo a Três Corações. Como se percebe, estamos a falar da região genericamente conhecida como o "Sul de Minas". 58

\footnotetext{
55 Vide MIRANDA, Marcos Paulo de Souza. Jurisdição dos capitães: a história de Januário Garcia Leal, o Sete Orelhas e seu bando. Belo Horizonte: Del Rey, 2003.

56 Vide Id. Ibid., p. 61.

57 Vide Id. Ibid., p. 61. (Os grifos em itálico são nossos).

58 MEIRELLES, José Teixeira de. A vida de Januário Garcia, o Sete Orelhas, apud MIRANDA, Marcos Paulo 
A fazenda onde residia João Garcia Leal confrontava com a propriedade de um indivíduo "inculto, ignorante e velhaco chamado Francisco da Silva ou Chico Silva, como era mais conhecido". ${ }^{59}$ As divisas das duas fazendas teriam sido estabelecidas judicialmente, tendo requerido o trabalho de agrimensores. Estes haviam fixado os rumos e os pontos por onde deveriam passar os valos que serviriam de marcos divisórios. Vamos dar a palavra, uma vez mais, ao autor da monografia:

Ocorreu que, logo que começou a abertura do valo, Francisco Silva, dotado de um instinto perverso, começou a colocar óbices na continuidade dos trabalhos, peitando os valeiros ou mandando mudar a direção da abertura da divisa em prejuízo do vizinho. Instado pelos Garcia, o mau vizinho, usurpador, trapaceava dando desculpas e dizendo que iria retificar as divisas, mas, na verdade, jamais cumpria com a sua palavra. ${ }^{60}$

Segundo José Teixeira de Meirelles, citado pelo autor, Januário Garcia Leal residia na mesma Fazenda Campo Formoso, e recebera dos seus pais "sensatas advertências" a respeito de Francisco Silva, o mau vizinho, e bem por este motivo o tratava "com muita prudência e ponderação", recebendo em contrapartida "ameaças e desaforos" ${ }^{61}$

Podemos perceber que estava potencialmente armado o palco para uma tragédia, com a existência de uma desavença sobre divisas de propriedades agrícolas, numa terra onde, como já nos foi dado verificar (retro, n. II) a autoridade estava, na prática, ausente... e a tragédia veio efetivamente a ocorrer!...

De acordo com as fontes idôneas que registraram a pendência, Francisco Silva era um esbulhador vulgar, desejoso de aumentar a área da sua fazenda, às expensas dos Garcia Leal. Nesta ordem de ideias, o abuso atingiu tais e tamanhas proporções, que os Garcia se viram na iminência de perder uma das suas melhores invernadas, chamada “O Pasto das Vacas". ${ }^{62}$ Em face de tal situação, João Garcia Leal buscou entender-se com os trabalhadores que abriam os valos divisórios para Francisco Silva, determinando a suspensão dos trabalhos. Atendendo à reclamação do vizinho, os trabalhadores deixaram o serviço e foram dar conta do acontecido ao seu patrão. ${ }^{63}$

Ao receber a notícia em sua sede, Francisco Silva "ficou possesso de cólera com tamanha audácia de João Garcia Leal". ${ }^{64}$ E, tendo chamado os seus filhos, deu-lhes uma ordem prenhe da mais refinada crueldade: - A eles determinou que procurassem João

de Souza. op. cit., p. 75.

59 Vide MIRANDA, Marcos Paulo de Souza. op. loc. cit.

60 Id. Ibid.

61 MEIRELlES, José Teixeira de. A vida de Januário Garcia, o Sete Orelhas, apud. MIRANDA, Marcos Paulo de Souza. op. e loc. cit.

62 Vide MIRANDA, Marcos Paulo de Souza. op. cit., p. 75 e 76.

63 Vide Id. Ibid., p. 76.

64 MIRANDA, Marcos Paulo de Souza. Jurisdição dos capitães: a história de Januário Garcia Leal, o Sete Orelhas e seu bando. Belo Horizonte: Del Rey, 2003. 
Garcia, e o atassem vivo a uma árvore, tirando-lhe a pele estando ele vivo, trazendo-a a ele, Francisco, e deixando o corpo exposto às aves de rapina. ${ }^{65}$

Eram sete os filhos de Francisco Silva que receberam a desalmada ordem do desalmado pai: - Luis, Carlos, Antônio, Joaquim, Francisco, Paulino e Bento. No dizer de Marcos Paulo de Souza Miranda, “Os irmãos Silva, como eram conhecidos, tinham a mesma índole de seu pai; eram rapazes robustos e sadios, mas de péssima educação e nenhuma moral". De acordo com o autor, "eram feras e não homens que ali estavam". ${ }^{66}$

Dias depois, João Garcia Leal, montado, saiu à procura de algumas reses tresmalhadas, tendo, neste intento, adentrado o "Pasto do Córrego" ou "Ribeirão do Cervo", uma invernada de grande extensão. Foi surpreendido pelos Irmãos Silva, que cumpriram a bárbara determinação que lhes fora dada pelo pai. Amarrado a uma figueira, o infeliz João foi despido, tendo os facínoras executado a sua nefanda tarefa de lhe tirar a pele, estando a vítima viva... o corpo ficou exposto aos urubus. ${ }^{67}$

Depois de relatar o episódio que procuramos resumir, escreve Marcos Paulo de Souza Miranda, "verbis":

Muitos são os que duvidam da veracidade da história que acabamos de narrar, com base na literatura mais autorizada existente sobre Januário Garcia Leal.

É óbvio que os detalhes são demasiados para serem críveis em sua integridade, mas não podemos simplesmente ignorar o que a tradição oral cuidou de guardar. Ademais, provas documentais, embora indiretas, evidenciam que algo de muito sério aconteceu, de forma a desviar a conduta escorreita de Januário a ponto de deixar sua família e se dedicar a bárbaros atos de vingança.

Particularmente, acreditamos que realmente foi o assassinato de João Garcia Leal o motor propulsor de todos os acontecimentos que analisaremos mais adiante. ${ }^{68}$

E aduz o autor que historiadores sérios, como José Guimarães e Hildebrando Campestrini confirmam o fato de que João Garcia Leal foi realmente assassinado. Campestrini, aliás, colheu informações junto aos descendentes de João Garcia Leal, em Mato Grosso do Sul.

Numa observação pessoal, lembramos que a tradição oral guarda, na memória do povo, os fatos históricos mais relevantes - ou mais impressionantes. Pois bem, refere Marcos Paulo de Souza Miranda que o local onde João Garcia Leal encontrou a morte, "guarda em sua denominação a lembrança do bárbaro crime ali cometido". Com efeito, acrescenta o autor, decorridos mais de duzentos anos, ainda existe a seis quilômetros da

\footnotetext{
65 MIRANDA, Marcos Paulo de Souza. Jurisdição dos capitães: a história de Januário Garcia Leal, o Sete Orelhas e seu bando. Belo Horizonte: Del Rey, 2003. . (Os grifos em itálico são nossos).

66 Id. Ibid.

67 Vide Id. Ibid., p. 77.

68 Vide Id. Ibid., p. 78. (Os grifos em itálico são nossos).
} 
pequena cidade de São Bento Abade, a figueira do "Tira-Couro". Este é o nome do lugar do assassinato, desde então. ${ }^{69}$

Temos que consignar que, tardando João Garcia Leal na busca das reses, foi procurado por seu irmão Januário, que encontrou, junto à figueira, os macabros despojos do homem assassinado pelos Irmãos Silva. ${ }^{70}$

6. As providências tomadas por Januário Garcia Leal diante do assassinato do irmão, e a inércia das autoridades constituídas

Já vimos que Januário Garcia Leal era, na hierarquia social do Brasil Colônia, aquilo que convencionalmente era chamado de "Homem Bom", o que significava ser branco, livre, proprietário e cristão velho... e tanto é assim que, conforme vimos "retro", sob o n. IV, foi ele indicado pela Câmara Municipal de Campanha, para $o$ importantíssimo cargo de Capitão de Companhia de Ordenanças. Era, ademais disto, na sua vida particular, homem austero, honesto e respeitador das leis.

Como súdito de El-Rei cumpridor dos seus deveres, como homem de bem, Januário, após o bárbaro assassinato do seu irmão João Garcia Leal, acionou as autoridades constituídas da Capitania das Minas Gerais. O relato de José Teixeira de Meirelles carece de ser aqui parcialmente reproduzido. Escreve o cronista, de maneira assaz saborosa:

Deitou em seguida por cima do arreio de seu cavalo o corpo de seu irmão, rumando com ele para a igreja de São Bento, que fica a meia légua, mais ou menos, onde, depois de render-lhe a última homenagem, deu-lhe sepultura. Voltando para casa, enquanto meditava, ainda meio passado pelo choque que passara, Januário limpou e azeitou, com muito capricho, a sua espingarda não esquecendo de aguçar cautelosamente o seu punhal, munindo-se de material necessário para viajar. Chamou seus escravos de mais confiança, entregou-lhes a direção da fazenda com as devidas recomendações; não dizendo para onde ia, mas que, em tempos incertos estaria de volta. Partiu Januário em direção às comarcas mais vizinhas que ficavam a quase trinta léguas de sua fazenda, que eram a do Bom Jardim e do Rio das Mortes. Lá chegando, procurou as autoridades competentes, dando parte do bárbaro crime, pedindo a punição dos criminosos.

As autoridades pouca atenção prestaram às suas queixas, levando em consideração a distância e a dificuldade de por em ação qualquer plano.

\footnotetext{
69 MIRANDA, Marcos Paulo de Souza. Jurisdição dos capitães: a história de Januário Garcia Leal, o Sete Orelhas e seu bando. Belo Horizonte: Del Rey, 2003. p. 79 e 80.

70 Vide Id. Ibid., p. 81 "usque" 84.
} 
Januário Garcia vendo seus planos irem por água abaixo, resolveu fazer justiça com suas próprias mãos, dando fim à vida dos Silvas, e como sentença a cada um cortar-lhes uma orelha. ${ }^{71}$

Atentemos para o dado apontado por Meirelles, pleno de significado ético, jurídico e político: - A vingança longe esteve de ser um "prius" na alma de Januário Garcia Leal. O desígnio de levá-la a cabo foi uma decorrência da inércia, ou da efetiva impotência, isto pouco importa, das autoridades constituídas da Capitania das Minas Gerais!... sem compreender este dado, verdadeiramente básico, não poderemos compreender o fenômeno da "Jurisdição dos Capitães", de que aqui nos ocupamos.

Aqui não nos alongaremos na descrição pormenorizada da vingança levada a cabo pelo antigo Capitão de Ordenanças. É o bastante dizer que os sete perversos matadores de João Garcia Leal foram todos mortos pelo Capitão Januário, que colecionou as suas orelhas. Ele foi auxiliado por seu irmão Salvador Garcia Leal e por seu primo Mateus Luis Garcia, conforme o relato de Marcos Paulo de Souza Miranda, que contradiz, neste ponto, o afirmado por José Teixeira de Meirelles. ${ }^{72}$ Os três membros da Família Garcia eram, ademais, acompanhados por "outros indivíduos socialmente considerados inferiores à época, tais como escravos e fugitivos da Justiça". ${ }^{73}$ É desta forma que nasce a "Jurisdição dos Capitães", da qual passamos a nos ocupar.

\section{A vingança de Januário Garcia Leal e a justiça privada nas Minas Gerais}

Conforme nos foi dado verificar, o antigo Capitão de Ordenanças se transformou em vingador, em função da absoluta inércia das autoridades constituídas da Capitania das Minas Gerais, em face do assassinato de João Garcia Leal, levado a cabo com requintes de sádica perversidade. Verificamos por igual que o vingador não atuou sozinho, contando ao revés com o apoio de dois familiares seus. Ao grupo se agregaram outras pessoas, de extração social inferior. Agora, com base neste dado, examinaremos a Justiça Privada e o seu exercício na indigitada Capitania de Minas Gerais.

Escreve a propósito Marcos Paulo de Souza Miranda, "verbis":

Ao que tudo indica, durante a perseguição dos homicidas, os Garcia acabaram se envolvendo em outros fatos que a Justiça oficial não conseguia resolver e passaram a fazer Justiça pelas próprias mãos, decidindo sobre o direito dos contendores.

\footnotetext{
71 MEIRELLES, José Teixeira de. A vida de Januário Garcia, o Sete Orelhas, p. 24 a 26, apud. MIRANDA, Marcos Paulo de Souza, op. cit., p. 83.

72 Vide MIRANDA, Marcos Paulo de Souza. op. cit., p. 101.

73 Id. Ibid.
} 
O caminho pelo qual haviam enveredado não tinha volta. Já estavam à margem da lei e nada tinham mais a temer, porque não deixariam de vingar o assassinato de João Garcia e sabiam que este fato, por si só, era suficiente para condená-los à morte. ${ }^{74}$

Deve aqui ser consignado que Mateus Luis Garcia era, como o seu primo Januário Garcia Leal, Capitão de Ordenanças, com Carta Patente expedida aos 24 de maio de 1803, sendo que Salvador Garcia Leal, irmão de Januário, era Alferes das citadas Companhias desde 27 de outubro de 1802. Tratava-se de homens de bem, de varões íntegros, escrevendo Marcos Paulo de Souza Miranda, "verbis":

A ação conjunta de Januário, Salvador e Mateus Garcia, pessoas que sempre tiveram uma vida fundada na dignidade, sendo merecedores de patentes de importantes cargos militares nos conduz à conclusão de que realmente os atos violentos que cometiam tinham fundamento em um assunto de família. Não há outra explicação para o fato. Os Garcia eram tidos como homens de bem, honestos $e$ honrados, tanto que inúmeros deles foram merecedores de altos postos militares e relevantes cargos públicos. Somente algo de muito sério poderia fazer com que aqueles homens deixassem de lado a conduta retilínea de suas vidas, o aconchego de suas casas, o carinho de suas famílias, para arriscarem suas vidas cometendo barbáries em lugares ermos, sabendo que a espada da justiça - que um dia procuraram nos fóruns mineiros - poderia vir a pesar sobre suas próprias cabeças. ${ }^{75}$

Reputamos importantíssimo o asseverado pelo ilustre Promotor de Justiça das Alterosas. O Autor fala em um "assunto de família". E isto é altamente sintomático. A família é o primeiro grupo natural, anterior e superior ao Estado. Ela é ademais - se assim podemos nos expressar - a "primeira escola". Os valores que guiarão um indivíduo ao longo de toda a sua vida, são hauridos na família, tendo observado com razão um civilista francês que, no colo de uma mãe virtuosa, se forma o que há de mais precioso para uma Nação, a saber, um homem de bem. Januário, Salvador e Mateus eram oriundos os três de família sólida e dotada de rígidos princípios morais. E a própria fidelidade que tinham aos afetos familiares, é um indicador, seguro, do seu bom caráter. Mas não se trata apenas disto: Antes de se entregarem ao exercício da Justiça Privada, haviam buscado - sem sucesso - o concurso da autoridade constituída, para a punição dos assassinos de João Garcia Leal.

A Justiça Privada desses Capitães das Ordenanças foi exercitada em uma parte considerável da Capitania das Minas Gerais. O Autor de "Jurisdição dos Capitães",

\footnotetext{
74 Vide MIRANDA, Marcos Paulo de Souza. Jurisdição dos capitães: a história de Januário Garcia Leal, o Sete Orelhas e seu bando. Belo Horizonte: Del Rey, 2003.

75 Vide Id. Ibid., p. 101 e 102. (Os grifos em itálico são nossos).
} 
em sua erudita obra, apresenta na página 69 um mapa da Capitania de Minas Gerais, que traz a legenda “Área de atuação da “jurisdição dos capitães”. O mapa em questão é revelador, abrangendo a zona compreendida entre Campanha, ao Sul, e Itapecerica ao Norte, São João Del Rei a Leste, e as divisas da Capitania de São Paulo, a Oeste. É perceptível que tal área de atuação coincide justamente com a região aurífera, que em função da decadência da mineração no final do século XVIII (retro, n. II), sofria o abandono por parte das autoridades — inclusive judiciárias — da Coroa Portuguesa... não é possível destarte, separar a inércia e a omissão das autoridades constituídas, dessa “Justiça Privada" exercitada em Minas Gerais, nos primeiros anos do século XIX: Trata-se de fenômenos correlatos, segundo o nosso modesto entendimento.

Esta Justiça Privada foi poderosa, escrevendo Marcos P. de Souza Miranda:

A história de Januário Garcia Leal e seu bando certamente é o mais expressivo exemplo na história mineira, e quiçá do Brasil, dessa verdadeira jurisdição privada exercida pelos antigos capitães. ${ }^{76}$

É altamente eloquente, a respeito da existência e da pujança da "Jurisdição dos Capitães”, a petição dirigida pela Câmara da Vila de São Bento do Tamanduá ao Governo português, em que ficou consignado o seguinte trecho, que reproduzimos:

Desta perniciosa quadrilha, quem mais se tem distinguido em atrocidades e por isso respeitado e tido como cabecilha é Januário Garcia Leal, que não satisfeito de ter dado a morte a mais de quinze pessoas, como é constante, passou já a usurpar o poder e jurisdição dos Ministros de Vossa Alteza, mandando com despótico e atrevido atentado por mais de uma vez impor perpétuo silêncio em pleitos judiciais, que corriam nos Auditórios desta Vila, pelas ameaças feitas aos advogados das partes a que não favorece. Outras vezes ele mesmo em pessoa fazendo-se árbitro das fazendas alheias, decide das dúvidas com absoluto império, sem deixar ao oprimido ao menos o desforço de queixar-se pelo justo receio de ser assassinado; e ultimamente, não se satisfazendo este régulo de obrar tão livre e sem respeito às justiças de Sua Alteza, de companhia com seu tio Mateus Luis Garcia, foi à casa e fazenda do Capitão Manuel Martins Parreiras, um dos Juízes Ordinários desta Vila e seu Termo, armados de bacamartes, pistolas traçados e facas para o violentarem e recolher e invalidar a ordem que tinha dado para ser preso Reinaldo Martins da Silva, criminoso de uma morte. ${ }^{77}$

\footnotetext{
76 Vide MIRANDA, Marcos Paulo de Souza. Jurisdição dos capitães: a história de Januário Garcia Leal, o Sete Orelhas e seu bando. Belo Horizonte: Del Rey, 2003. p. 66. (Grifos em itálico no original).

77 Vide MIRANDA, Marcos Paulo de Souza. Jurisdição dos capitães: a história de Januário Garcia Leal, o
} 
Cremos que nada mais carece ser dito. As palavras dos Vereadores que acabamos de reproduzir, são o bastante para comprovar a existência e, mais do que isto, a pujança da "Jurisdição dos Capitães".

8. O apoio de pessoas influentes aos justiceiros

Diante dos desmandos dos justiceiros, o Capitão-General de Minas Gerais, aos 5 de novembro de 1803, endereçou correspondência dirigida a todos os CapitãesMores de Minas Gerais, determinando que fosse preso em flagrante delito qualquer integrante do bando de Januário Garcia Leal, que tivesse cometido violências. ${ }^{78}$ De resto, houve também uma ordem, emanada do próprio Príncipe Regente D. João - o futuro Rei D. João VI - no sentido de que fossem presos Januário, Salvador e Mateus, todos os três, como temos visto, integrantes da Família Garcia. Esta ordem de Sua Alteza Real era a resposta à Representação que havia sido feita pela Câmara Municipal de São Bento do Tamanduá, e que em parte transcrevemos (retro, n. VII). ${ }^{79}$

Escreve Marcos Paulo de Souza Miranda que o Governador de Minas sabia muito bem que não seria tarefa fácil prender os Garcia: - Tratava-se de homens respeitados e com muitos parentes na Capitania, o que dificultaria muito a perseguição a eles... ${ }^{80}$ foi escolhido para a árdua tarefa o Sargento-Mor Fernando Vasconcelos Parada e Souza, que obtivera destaque, como militar, nos acontecimentos da Inconfidência Mineira.

Sucede que Januário, Salvador e Mateus foram protegidos pelo Padre João Pereira, seu parente muito próximo. Foram ainda protegidos pelo Padre Antônio Caetano de Almeida Vilas Boas, Vigário de São João Del Rei, escrevendo a propósito Marcos Paulo de Souza Miranda, "verbis":

O apoio e a proteção do Vigário de São João Del Rei, Antônio Caetano de Almeida Vilas Boas, a Mateus Luis Garcia e, indiretamente, a Januário e Salvador, é testemunho eloqüente de que os Garcia eram pessoas que desfrutavam de alta consideração no meio das autoridades da Comarca do Rio das Mortes. ${ }^{81}$

Salvador Garcia Leal acabou sendo preso, com efeito. Porém Mateus Luis Garcia logrou escapar de ser preso pelo tenaz Sargento-Mor Fernando Vasconcelos Parada e Souza. O cerco contra os dois justiceiros ainda em liberdade apertava cada vez

Sete Orelhas e seu bando. Belo Horizonte: Del Rey, 2003. p. 67 e 68. (Os grifos em itálico são nossos).

78 Vide Id. Ibid., p. 121.

79 Id. Ibid., p. 122.

80 Id. Ibid.

81 Vide MIRANDA, Marcos Paulo de Souza. Jurisdição dos capitães: a história de Januário Garcia Leal, o Sete Orelhas e seu bando. Belo Horizonte: Del Rey, 2003. p. 133. (Os grifos em itálico são nossos). 
mais. Januário Garcia Leal contava, à época, cerca de quarenta e cinco anos, sendo um homem vigoroso, e apto a suportar as rudezas do sertão. Porém com Mateus Luis Garcia, sexagenário e alquebrado, não ocorria isto. Assim, acabou por escrever ao Príncipe Regente de Portugal, implorando a proteção real e pedindo que não fosse preso antes que fosse aferida a sua culpa nos fatos de que era acusado. ${ }^{82}$ A petição não foi deferida.

Quanto ao temido e temível Capitão Januário Garcia Leal, alcunhado o "Sete Orelhas", jamais foi preso, tendo literalmente desaparecido. Lendas surgiram a respeito, algumas afirmando que, depois de passar algum tempo no anonimato, o justiceiro teria voltado ao convívio social. Mas, nada existe de concreto a respeito, escrevendo Marcos Paulo de Souza Miranda:

Como se vê, ainda há muito o que se descobrir sobre a vida de Januário Garcia Leal. As dúvidas acerca de sua biografia começam com o seu nascimento e se estendem até a sua morte. $^{83}$

Uma coisa pode, pensamos, ser considerada certa: - Sem o apoio firme de pessoas influentes, entre elas eclesiásticos e membros da hierarquia militar da Capitania das Minas Gerais, Januário Garcia Leal e os seus seguidores teriam sido presos, com rapidez, tão logo foram dadas as necessárias ordens neste sentido. E tal apoio não existiria se a própria Jurisdição dos Capitães não fosse vista com simpatia, de maneira positiva, pela população da Capitania...

9. A atualidade do problema aqui enfocado

Ao tratar do fim da Jurisdição dos Capitães, escreve Marcos Paulo de Souza Miranda:

Como vimos, durante vários anos Januário Garcia Leal, Salvador Garcia Leal e Mateus Luis Garcia andaram pela Capitania de Minas Gerais fazendo justiça.

Os bravos milicianos, diante da inércia absoluta do poder judiciário colonial quanto à apuração do repugnante e covarde crime que vitimou o jovem fazendeiro João Garcia Leal, não se conformaram com a impunidade dos matadores. Passaram, então, eles próprios, a investigar os autores do crime, persegui-los e sentenciá-los. A lei escolhida pelos justiceiros foi a de Talião: morte aos matadores. E não hesitaram em aplicá-la, extraindo, como prova de que a justiça - ainda que não a do Estado - existia naqueles rincões das Minas Gerais, uma orelha de cada indivíduo justiçado.

$82 \quad$ Vide Id. Ibid., p. 131.

83 Vide Id. Ibid., p. 142. 
Durante o longo período de perseguição aos criminosos, os justiceiros privados acabaram se envolvendo em outros fatos, e indignados com a falta de justiça na Capitania acabaram agindo por conta própria, resolvendo os mais variados tipos de conflitos sociais, tais como disputas sobre divisas, cobrança de dívidas, legalidade de transações imobiliárias etc.

Chegou a um tal ponto que em Minas se podia falar na existência de duas justiças: a do Estado português, lenta, burocrática e ineficaz; e a dos Garcia, célere imperativa e implacável. ${ }^{84}$

As candentes palavras do ilustre membro do Ministério Público de Minas Gerais nos levam a meditar sobre a realidade da nossa própria época. A omissão, e mesmo a ausência do Estado no que tange a proporcionar, aos cidadãos, segurança e acesso à Justiça, são fatores que não podem mais ser ignorados. E, na ausência do Estado, é fatal que alguém surja, para exercitar um Poder de Polícia paralelo, e mesmo uma Jurisdição paralela. Isto é preocupante, pois existe a respeito um dado sociológico que peço vênia para chamar de "tétrico": - Ao tempo de Januário Garcia Leal e dos seus seguidores, a função de justiceiros foi exercida por homens bem-nascidos e bem formados, dotados de uma escala de valores confiável. Agora, esta função vem sendo exercida por integrantes do crime organizado, vale dizer, pelos narcotraficantes. Januário Garcia Leal, Capitão das Ordenanças, é substituído por Fernandinho Beira-Mar, Marcola, "et magna infectumque caterva"!... E passemos às nossas conclusões finais.

\section{Conclusão}

O Estado tem que se fazer presente e visível. Presente no policiamento preventivo e repressivo, e presente na efetiva e rápida prestação jurisdicional. O Estado está acovardado, porque antes disto a Nação, de que ele é instrumento, também está acovardada.

$\mathrm{O}$ que aqui aconselhamos passa pelo endurecimento do Direito Penal. Ou adotamos um Direito Penal efetivamente retributivo e enérgico, ou a sociedade, refém do crime organizado, haverá de soçobrar. Esta é a única maneira de obviar o surgimento de modernas - e mais macabras - "Jurisdições" paralelas. O problema passa pelo abandono da superada pena de prisão. Mas este é assunto para um outro momento.

Agradeço a atenção com que fui ouvido. Muito obrigado!

São Paulo, novembro de 2010.

84 Vide MIRANDA, Marcos Paulo de Souza. Jurisdição dos capitães: a história de Januário Garcia Leal, o Sete Orelhas e seu bando. Belo Horizonte: Del Rey, 2003. p. 143. (Grifo em itálico no original). 


\section{Referências}

ALMEIDA JUNIOR, João Mendes de. Direito judiciário brasileiro. 5. ed. Rio de Janeiro/São Paulo: Livraria Freitas Bastos S.A., 1960.

ARANGIO-RUIZ, Vincenzo. Storia Del Diritto Romano. Sesta edizione riveduta. Napoli: Casa Editrice Dott. Eugenio Jovene, 1950.

CAMÕES, Luiz Vaz de. Os Lusíadas. 5. ed. Edição escolar comentada pelo Professor Otoniel Mota. São Paulo: Edições Melhoramentos, s/d.

CARVALHO, José Baptista de. A verdadeira história das capitanias hereditárias. São Paulo: Edição do autor, 2008.

CUNHA, Antonio Geraldo da. Dicionário etimológico nova fronteira da língua portuguesa. 1. ed., 2. reimp. Rio de Janeiro: Nova Fronteira, 1982.

DE CICCO, Claudio. Direito: tradição e modernidade. São Paulo: Ícone Editora Ltda., 1993.

FIRMINO, Nicolau. Dicionário Latino-Português. 2. ed. rev. e ampl. São Paulo: Edições Melhoramentos, s/d.

GLOTZ, Gustave. A Cidade Grega. 2. ed. Tradução de Henrique de Araujo Mesquita e Roberto Cortes de Lacerda. Rio de Janeiro: Editora Bertrand Brasil S.A., 1988. (Original em Francês).

LEME, Pedro Taques de Almeida Paes. Notícias das Minas de São Paulo e dos Sertões da mesma capitania. Segunda tiragem da edição comemorativa do IV Centenário da Fundação de São Paulo, introdução e notas de Afonso de E. Taunay. São Paulo: Livraria Martins Editora S.A.

LIMA FILHO, Acacio Vaz de. O poder na Antigüidade: aspectos históricos e jurídicos: São Paulo: Ícone Editora Ltda., 1999.

. Liberdade antiga e liberdade moderna, no pensamento de Miguel Reale. Revista Brasileira de Filosofia, São Paulo, v. 55, n. 222, abr./jun. 2006.

MARQUES, José Frederico. Instituições de direito processual civil. 1. ed. Rio de Janeiro: Forense, 1958, v. 1 .

MIRANDA, Marcos Paulo de Souza. Jurisdição dos capitães: a história de Januário Garcia Leal, o Sete Orelhas, e seu bando, Belo Horizonte, Del Rey, 2003.

REALE, Miguel. Horizontes do direito e da história. 2. ed. rev. e aumen. São Paulo: Saraiva, 1977. . Lições Preliminares de direito. São Paulo. 27. ed. ajustada ao novo Código Civil, 4. tir. São Paulo: Editora Saraiva, 2004.

SARAIVA, F. R. dos Santos. Dicionário Latino-Português. Belo Horizonte/Rio de Janeiro: Livraria Garnier, 2006.

TORRINHA, Francisco. Dicionário Latino-Português. 3. ed. Porto: Edições Marânus, 1945. 
